\title{
Improved Electrothermal Determination of Aluminum in Serum by Atomic Absorption Spectroscopy
}

\section{Frances R. Alderman and Hillel J. Gitelman}

We describe an improved method for determination of aluminum in serum by atomic absorption spectrophotometry with a graphite furnace. Interferences have been controlled and total combustion of the samples achieved by the use of new diluent in a molybdenum-treated graphite tube. The detection limit of this method is $2 \mu \mathrm{g} / \mathrm{L}$.

\section{Additional Keyphrases: dialysis dementia - hemodial- ysis}

A possible association between aluminum and dialysis dementia, a progressive encephalopathic syndrome in hemodialysis patients $(1,2)$, prompted us to measure the serum aluminum in our hemodialysis patients. In determining aluminum with the graphite furnace, we encountered difficulties that we believe were related to a residue produced by the injection of undiluted serum (3). Reasoning that the formation of residue could be minimized by injection of an appropriately diluted serum sample, we have developed a diluent that eliminates residue formation. This diluent is the basis for an improved method for determining aluminum in serum.

\section{Materials and Methods}

\section{Equipment}

We used a Model 403 atomic absorption spectrophotometer equipped with a Model HGA-2000 graphite furnace, a deuterium background corrector, and standard graphite cones and tubes, all from Perkin-Elmer Corp., Norwalk, CT 06856. The spectrophotometer output was recorded with a Speedomax XL 680 recorder (Leeds and Northrop, North Wales, PA 15454). We injected $20-\mu \mathrm{L}$ aliquots into the graphite tubes with a Precision liquid dispenser (Hamilton Co., Reno, NV 89510) equipped with a Teflon needle and controlled by a foot valve (4). An all-Teflon and glass reagent dispenser (Glenco Scientific, Houston, TX 77007) dispensed the sample diluent into $16 \times 100 \mathrm{~mm}$ polycarbonate tubes. The hollow-cathode aluminum lamp was from Fisher Scientific Co., Pittsburgh, PA 15219.

\section{Standards and Reagents}

Standards. A 1000 -ppm ( $1000 \mu \mathrm{L} / \mathrm{L})$ certified atomic absorption aluminum reference solution (Fisher Scientific) was used to prepare standards. Aliquots of this stock were diluted with dilute $\mathrm{HNO}_{3}(1 \mathrm{~mL} / \mathrm{L}$, Ultrex grade; J. T. Baker Co., Phillipsburg, NJ 08865) to yield working standards containing between 50 and $600 \mu \mathrm{g}$ of aluminum per liter. To avoid contamination, we found it necessary to rinse the Parafilm squares used for capping the dilutions.

Samples. Blood was collected in red-top Vacutainer Tubes (Becton Dickinson Co., Rutherford, NJ 07070). After clotting and centrifugation, the serum was removed with disposable glass Pasteur pipettes and stored in rubber-stoppered $13 \times$

Department of Medicine, University of North Carolina, School of Medicine, Chapel Hill, NC 27514.

Received Aug. 13, 1979; accepted Nov. 21, 1979.
$100 \mathrm{~mm}$ unused, disposable glass tubes, all found to be aluminum free.

Diluent. This solution contains, per liter, $20 \mathrm{mmol}$ of disodium ethylenediaminetetraacetate (EDTA) (Fisher), 83.5 $\mathrm{mL}$ of $200 \mathrm{~mL} / \mathrm{L} \mathrm{NH}_{4} \mathrm{OH}$ (Ultrex, J. T. Baker Co.), $10 \mathrm{~mL}$ of $\mathrm{H}_{2} \mathrm{SO}_{4}$ (Ultrex, J. T. Baker Co.), and $10 \mathrm{~mL}$ of Triton X-100 (scintillation grade; Mallinckrodt Inc., St. Louis, MO 63147). This solution is stable indefinitely when stored in a polyethylene bottle but should not be stored in the dispenser, because the aluminum reading of this solution will increase during overnight storage.

Ammonium molybdate solution. Dissolve $9.2 \mathrm{~g}$ of $\left(\mathrm{NH}_{4}\right)_{6} \mathrm{Mo}_{7} \mathrm{O}_{24} \cdot 4 \mathrm{H}_{2} \mathrm{O}$ in $40 \mathrm{~mL}$ of $50 \mathrm{~mL} / \mathrm{L} \mathrm{NH} \mathrm{NH}_{4} \mathrm{OH}$ (Ultrex, J. T. Baker Co.); dilute to $50 \mathrm{~mL}$ with distilled water, mix, then add $1 \mathrm{~mL}$ of $n$-propanol. This solution contains about $100 \mathrm{~g}$ of molybdenum per liter and is used to precondition graphite tubes.

Cleaning solution for polycarbonate tubes. This solution contains, per liter, $10 \mathrm{mmol}$ of $\mathrm{Na}_{2} \mathrm{CO}_{3}, 1.0 \mathrm{mmol}$ of disodium EDTA, $2.0 \mathrm{mmol}$ of sodium citrate, and $0.15 \mathrm{~mL}$ of Triton $\mathrm{X}-100$. Soak the polycarbonate tubes in this solution for at least $4 \mathrm{~h}$, then extensively and carefully rinse them with distilled water immediately before each use. We used distilled water that had been de-ionized and then redistilled in glass throughout this procedure; it contained no detectable aluminum.

\section{Graphite Tube Treatment}

Immerse the graphite tube in the ammonium molybdate solution under reduced pressure for $5 \mathrm{~min}$, then insert the wet tube into the furnace in the usual fashion. Several program firings are necessary to eliminate the nonspecific signals produced by the molybdenum treatment. No further treatment is necessary for the life of the tube, which we estimate to be about 200 to 300 firings.

\section{Procedure}

Use a 1:1 dilution for samples containing less than $150 \mu \mathrm{g}$ of aluminum per liter. Use a fivefold sample dilution for samples containing between 150 and $600 \mu \mathrm{g} / \mathrm{L}$ (the usual dilution used with serum from hemodialysis patients). Dispense 100 - or $400-\mu \mathrm{L}$ samples consisting of serum, distilled water (for the reagent blank), or appropriate standards with a 1-mL "Selectapette" (Clay Adams), using a disposable polypropylene tip. The standard curve for both dilutions is linear, so either dilution can be standardized by running the highest standard and reagent blank.

To minimize contamination, perform all operations under dust covers. We rinsed the pipette tips with distilled water and discarded two sample volumes of the specimen before dispensing samples for analysis. We found it convenient to make quadruplicate sample dilutions, even though only two or three dilutions are usually necessary to achieve reproducible results. This practice minimizes the chance of sample contamination from a new pipette tip. Make dilutions immediately before injection to minimize the potential for contamination from prolonged standing. Results are considered reproducible when 


\section{Table 1. Instrument and Furnace Settings}

Atomic absorption and spectrophotometer

Aluminum hollow-cathode lamp current: $16 \mathrm{~mA}$.

Wave length: $309.2 \mathrm{~nm}$

Slit: $0.7 \mathrm{~nm}$ (No. 4)

Phase: normal

Gain: center of energy meter

Deuterium lamp: energy matched to aluminum lamp

Mode: absorbance

Scale: $0.25 \mathrm{~A}$

Curve correction onset and magnitude: 0

Recorder response: 1 (undamped)

Graphite furnace program

Argon gas, flowmeter at 4.5 arb. units

Recorder: automatic

Gas interrupt: automatic

Drying stage: $30 \mathrm{~s}$ at $400{ }^{\circ} \mathrm{C}$

Charring stage: $30 \mathrm{~s}$ at $1580^{\circ} \mathrm{C}$

Atomizing stage: $10 \mathrm{~s}$ at $2600^{\circ} \mathrm{C}$

\section{Chart recorder}

Range: $10 \mathrm{mV}$ full scale

Chart speed: $60 \mathrm{~cm} / \mathrm{h}$

Sample volume: $20 \mu \mathrm{L}$

Graphite tube: preconditioned by soaking in ammonium molybdate solution (see text)

Peak height response: 1 scale division = approximately $2 \mu \mathrm{g}$ of aluminum per liter in the final dilution

peak heights agree within 0.5 scale division at the lowest concentration of aluminum, or within $5 \%$ at higher concentrations.

Instrument and furnace settings required for the determination of aluminum are given in Table 1.

\section{Results}

Graphite tube treatment. Our evaluation of graphite tube treatment was prompted by our inability to obtain accurate recoveries of aluminum in serum samples with untreated tubes and by reports that graphite tube treatment with carbideforming elements diminishes interferences in other determinations $(5,6)$. In contrast to our experiences with untreated tubes, we observed complete and accurate recoveries of aluminum in serum with tubes that had been soaked in the ammonium molybdate solution. Because newer tubes appear to be more precise than older ones, we replace the graphite tubes when results become nonreproducible.

Furnace settings. The diluted serum specimens dry rapidly at $400^{\circ} \mathrm{C}$, producing no residue during the charring phase. The temperature and duration of drying are crucial factors in eliminating the negative interference associated with chloride in aqueous solutions and the tendency for enhanced recovery of aluminum in serum samples. We found that with temperatures between 400 and $450^{\circ} \mathrm{C}$ and times between 20 and $40 \mathrm{~s}$ we were able to control both factors. We chose to use char-cycle settings of $30 \mathrm{~s}$ and $1580^{\circ} \mathrm{C}$ after observing stable aluminum values and recoveries for serum with use of temperatures between 1550 and $16500^{\circ} \mathrm{C}$ and time intervals between 20 and $40 \mathrm{~s}$. Atomization temperature was set at 2600 ${ }^{\circ} \mathrm{C}$ after observing a diminished rate of increase in aluminum peak heights between 2600 and $2650^{\circ} \mathrm{C}$ in comparison with the rate of increase observed at lower temperatures. A plateau response could not be obtained. At this atomization temperature a 10-s atomization interval results in thorough purging of the graphite tube, as evidenced by the absence of sample carryover.

Sample diluent. Serum diluted with aqueous Triton X-100 does not produce a residue inside the graphite tube, but does display a 25 to $30 \%$ decrease in signal in the presence of 100 mmol of chloride per liter. Our attempts to modify the effect of chloride by ammonium nitrate, as has been done elsewhere (5), produced an inordinate recovery of aluminum in serum samples. In contrast, ammonium sulfate modified the effect of chloride without adversely altering aluminum recovery (see below). A sample containing $150 \mu \mathrm{g}$ of aluminum per liter of saline (100 mmol/L) displayed no chloride interference when diluted with an equal volume of $1.0 \mathrm{~mol} / \mathrm{L}$ ammonium hydroxide containing dilute $(10 \mathrm{~mL} / \mathrm{L})$ sulfuric acid. We included disodium EDTA in the diluent to obviate any colloidal precipitates of aluminum, especially when aqueous samples are mixed with alkaline solutions containing divalent cations and phosphate. Using the recommended diluent with aqueous samples containing $150 \mu \mathrm{g}$ of aluminum per liter, we observed no interference with $\mathrm{NaCl}(100 \mathrm{mmol} / \mathrm{L}), \mathrm{CaCl}_{2}(5 \mathrm{mmol} / \mathrm{L})$, $\mathrm{MgCl}_{2}(5 \mathrm{mmol} / \mathrm{L})$, or $\mathrm{KH}_{2} \mathrm{PO}_{4}(5 \mathrm{mmol} / \mathrm{L})$. Recovery values (Table 2) ranged from 99 to $104 \%$. The variability in percentage recovery observed with the addition of $15 \mu \mathrm{g}$ of aluminum per liter to normal sera can be attributed to the small amount of aluminum used and is consistent with complete recovery for the precision of the assay.

We prepared two pools of sera from hemodialysis patients to determine the reproducibility of the proposed method. Particulate material was removed by centrifugation and filtration. The serum pools had mean values for aluminum of 251 and $223 \mu \mathrm{g} / \mathrm{L}$, respectively, from individuals whose sera contained between 50 and $600 \mu \mathrm{g}$ of aluminum per liter. We observed a CV of $3.4 \%$ for 11 determinations made during a two-week period. To establish a reference value for aluminum in sera in normal individuals, we obtained 14 specimens from individuals in good health, who were not ingesting aluminum-containing products. We observed a mean value of 2.1 (SD 2.2) $\mu \mathrm{g}$ of aluminum per liter, with a range of 0.0 to 7.6.

\section{Discussion}

We believe the method we describe for the determination of aluminum in serum with use of a diluent has several advantages over the previously described technique in which undiluted serum is used (3). The diluent provides conditions that result in total combustion of a protein-containing sample during the char cycle, eliminating the problem of residue inside the graphite tube. Sample throughput is enhanced because there is no need to clean the tube between sample injections and because the time necessary for sample drying and charring is shortened. Matrix effects, primarily related to the presence of chloride, have been controlled. Therefore, the assay has become more rapid and precise.

We have not found the potential for aluminum contamination to be an insurmountable problem. Contamination has

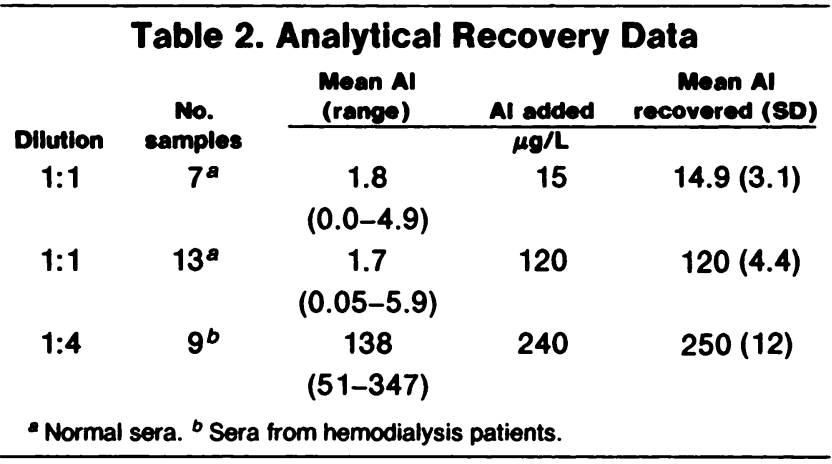


been minimized by the use of high-purity chemicals, aluminum-free water, and undeviating attention to the use of carefully rinsed tubes and vessels. Our reagent blank is equivalent to approximately $4 \mu \mathrm{g}$ of aluminum per liter for a 1:1 dilution. Because of the consistency of the background, we have found it possible to reliably detect $2 \mu \mathrm{g} / \mathrm{L}$.

We observe a lower range for serum aluminum in normal sera than has been reported elsewhere (3). We think it is likely that this is related to the absence of contamination in our specimens, because our recovery of aluminum added to normal sera is virtually complete.

\section{References}

1. Alfrey, A. C., LeGendre, G. R., and Kaehny, W. D., The dialysis encephalopathy syndrome: Possible aluminum intoxication. N. Engl. J. Med. 294, 184 (1976).

2. McDermott, J. R., Smith, A. I., Ward, M. K., et al., Brain aluminum concentration in dialysis encephalopathy. Lancet $\mathrm{i}, 901$ (1978).

3. Gorsky, J. E., and Dietz, A. A., Determination of aluminum in biological samples by atomic absorption spectrophotometry with a graphite furnace. Clin. Chem. 24, 1485 (1978).

4. Gitelman, H. J., An inexpensive and convenient semi-automated sample injector for the graphite furnace. At. Absorp. Newsl. 18, 99 (July-August, 1979).

5. Manning, D. C., and Slavin, W., Determination of lead in a chloride matrix with the graphite furnace. Anal. Chem. 50, 1234 (1978).

6. Driedger, A., and Getiz, W. R., Flame photometry of phosphorus vaporized from a silica-treated graphite furnace. Anal. Chem. 51, 1197 (1979). 